\title{
Environmental effect on genetic gains and its impact on bread-making quality traits in Brazilian spring wheat
}

\author{
Elesandro Bornhofen¹, Giovani Benin ${ }^{1 *}$, Lindolfo Storck ${ }^{1}$, Volmir S. Marchioro², \\ Cátia Meneguzzi ${ }^{1}$, Anderson S. Milioli', and Diego M. Trevizan¹
}

\section{ABSTRACT}

In wheat (Triticum aestivum L.) several studies have reported genetic gain for grain yield over the years. However, studies on wheat bread-making quality are scarce. Our objective was to estimate the progress due to genetic and environmental components in wheat breadmaking quality parameters. In addition, we aimed to examine trends in historical cultivars and associate traits performance with geographical parameters. We used data from multi-environment trials (MET) represented by eight years (2005-2012) and 458 genotypes, including lines and commercial cultivars (controls). We determined the genetic progress by the contrasts between genotypes assessed in each biennium, excluding the year effect. This effect is previously estimated by existing variation among common genotypes. Genotype replacement rate was 52\% and reflects the dynamism of the breeding program to develop better genotypes in terms of bread-making quality. The genetic progress estimated for gluten strength (W) was $1.30 \% \mathrm{yr}^{-1}$. The progress in $\mathrm{W}$ demonstrated to be partly counterbalanced by the environmental effect $\left(-0.78 \% \mathrm{yr}^{-1}\right)$. We observed disequilibrium tendency in relationship between tenacity and extensibility $(\mathrm{P} / \mathrm{L}$ ratio) as a consequence of searching for lines with high $\mathrm{W}$. Analysis showed that $\mathrm{P} / \mathrm{L}$ ratio can be reduced in responses to the increase in latitude of the location. Environmental and genetic effects on the traits variation were discussed.

Key words: Breeding contribution, genetic gain, gluten strength, old and modern cultivars, $\mathrm{P} / \mathrm{L}$ ratio, Triticum aestivum.
${ }^{1}$ Universidade Tecnológica Federal do Paraná, 85503-390, Pato Branco, Paraná, Brasil. "Corresponding author (benin@utfpr.edu.br). ${ }^{2}$ Cooperativa Central Agropecuária de Desenvolvimento Tecnológico e Econômico, BR 467, 85813-450 Cascavel, Paraná, Brasil.

Received: 21 July 2016.

Accepted: 20 January 2017.

doi:10.4067/S0718-58392017000100003.

\section{INTRODUCTION}

Wheat (Triticum aestivum L.) breeding in Brazil began in the 1920s in the southern region. At that time, two research stations were created. Over the years the goals of breeders changed, and recently the search for cultivars with high bread-making quality became a must. Results from $70 \mathrm{yr}$ of research into breadmaking quality were previously published by MacRitchie (2016) and point out some remarkables works on this research field. In 1994, the first regulation (regulation nr 167) was approved and established three classes for wheat bread-making quality: superior, intermediate and common (Brazil, 1994). Thereafter, breeders redirected efforts to develop lines with high breadmaking quality as well as high grain yield. Recently, regulation $\mathrm{n}^{\mathrm{o}} 38$ of 11/30/2010 (Brazil, 2010) increased the rigor for wheat classification regarding bread-making quality. As a result, it has become necessary to investigate the gains obtained in this period. Although some reports about bread-making quality have been published, none of them have measured the genetic gain in Brazilian wheat.

Since Brazil is a typical country dependent of bread wheat, it is necessary to dedicate efforts on development of new varieties with high yields and exceptional bread-making quality to improve market competitiveness. The bread-making quality is an important property and can be expressed by several traits, which are related to the complex of proteins, milling properties and baking performance. The alveography, a rheological analysis, measures the viscoelastic characteristics of the dough, providing the parameters: gluten strength $(\mathrm{W})$, tenacity $(\mathrm{P})$, extensibility (L) and the relationship between tenacity and extensibility $(\mathrm{P} / \mathrm{L})$. The falling number (FN) also determines the flour classification, being used for indirect evaluation of the alpha-amylase activity, estimating the degree of conversion of the starch into simple sugars (Atwell, 2001).

The genetic $(\mathrm{G})$, environment $(\mathrm{E})$ and their interaction $(\mathrm{G} \times \mathrm{E})$ components of variation impact the rheological properties of the dough (Vázquez et al., 2012; Li et al., 2013). When there are high effect of $\mathrm{E}$ and $\mathrm{G} \times \mathrm{E}$, difficulties occur in the selection process. This occurs mainly due to the decrease in the association between genetic and phenotypic values, affecting the genetic gain. In addition, these difficulties are increased as the differences between test environments are maximized. Alveographic parameters are modified significantly by the presence of heat $(\mathrm{Li}$ et al., 2013) and water stress. In this sense, Vázquez et al. (2012) suggested that breeding for baking quality should be adapted to 
target environments due to the importance of plant growth conditions on the traits variation.

Estimating genetic gain is essential for wheat breeding programs. This helps breeders in decision-making process to define appropriate goals and strategies for selecting cultivars with specific baking quality to meet the market requirements. Two ways to estimate the genetic gain are often used in evaluating the efficiency of breeding programs: i) conducting experiments with old and modern cultivars (Matus et al., 2012; Cormier et al., 2013, Bilgin et al., 2015), and ii) using data from multi-environment trials (Cargnin et al., 2008; Oury et al., 2012, CrespoHerrera et al., 2017). This last option is more attractive because it does not require a specific experimentation process, but just the data already available.

In Brazil, data from value for cultivation and use (VCU) trials were used to estimate genetic gain of breeding programs for rice (Atroch and Nunes, 2000), common bean (Ribeiro et al., 2003), and maize (Storck et al., 2005). Regarding wheat, there are studies (Cargnin et al., 2008; 2009), but they do not consider bread-making attributes. Indeed, prevailing factor in all the investigations is the breeding success in increasing grain yield potential, largely attributed to changes in biomass partitioning (Ormoli et al., 2015). In Triticum durum L. there are genetic gain reports of bread-making quality (De Vita et al., 2007; Subira et al., 2014). In T. aestivum there are evidences of high bread-making quality parameters in modern genotypes (Hucl et al., 2015; Ormoli et al., 2015; Sanchez-Garcia et al., 2015, Laidig et al., 2017). Nonetheless, genetic gain references for bread-making quality are insufficient. This is probably due to the high cost of laboratory analysis to determine the quality parameters of the flour samples.

We aimed with the present investigation to estimate the gain or losses due to genetic and environmental components on bread-making quality traits, examine trends in historical cultivars and associate the expression of these traits with geographical variables.

\section{MATERIALS AND METHODS}

\section{Plant material evaluated and field trials characteristics}

In order to investigate the genetic gain on wheat breadmaking traits, we used data from value for cultivation and use (VCU) trials in multi-environment (MET). All data were obtained from a wheat breeding program maintained by Central Agricultural Cooperative for Technology Development and Economics (COODETEC). They consist of trials conducted during the period from 2005 to 2012 across Brazilian crop areas. To perform the laboratory analysis, grain samples were obtained from some locations, mainly in VCUs in the regions 2 and 3 (Table 1).

Between 2005 and 2012, a set of 458 wheat genotypes were evaluated for the bread-making quality traits, generating 933 and 1165 observations in the cities of Cascavel and Palotina respectively, both in the state of Paraná in the southern Brazil (Figure 1, Table 1). In addition to these genotypes, 36 commercial cultivars were used as controls. Those cultivars represent genotypes that, over the time, had high acceptance by farmers and were widely cultivated across Brazil.

The experiments conducted at each site were arranged in a randomized complete block design (RCBD) with three replicates. The experimental units consisted of six rows 0.20 $\mathrm{m}$ apart with $5.0 \mathrm{~m}$ long by $1.2 \mathrm{~m}$ wide, totaling $6 \mathrm{~m}^{2}$. At each experiment, 25 treatments (lines and elite cultivars as controls) were tested. The implemented cultivation practices followed the guidelines on the technical information for wheat crop, published annually as a manual by Brazilian Wheat and Triticale Research Commission. In addition, the trials followed regulations established by the Brazilian Ministry of Agriculture, which are required for the registration and protection of new cultivars.

The plots were mechanically harvested and after grain yield evaluation, grain mass of the three replicates of each entry were mixed to compose the grain samples for

Table 1. Summary of the test sites where wheat genotypes are evaluated for bread-making quality parameters in the COODETEC breeding program.

\begin{tabular}{|c|c|c|c|c|c|c|}
\hline & \multirow[b]{2}{*}{ City-State } & \multirow[b]{2}{*}{$\mathrm{VCU}^{1}$} & \multirow[b]{2}{*}{$\mathrm{n}$} & \multicolumn{3}{|c|}{ Geographic coordinates ${ }^{2}$} \\
\hline & & & & Latitude & Longitude & Elevation \\
\hline 1 & Luziânia-Goiás (GO) & 4 & 23 & 16.2514 & 47.9177 & 930 \\
\hline 2 & Catalão-GO & 4 & 16 & 18.1661 & 47.9445 & 835 \\
\hline 3 & São Gotardo-Minas Gerais & 4 & 57 & 19.3092 & 46.0469 & 1055 \\
\hline 4 & Dourados-Mato Grosso do Sul & 3 & 40 & 22.2235 & 54.8125 & 430 \\
\hline 5 & Palotina-Paraná (PR) & 3 & 1165 & 24.2866 & 53.8405 & 335 \\
\hline 6 & Abelardo Luz-Santa Catarina (SC) & 2 & 152 & 26.5663 & 52.3276 & 760 \\
\hline 7 & Santo Augusto-Rio Grande do Sul (RS) & 2 & 55 & 27.8531 & 53.7781 & 528 \\
\hline 8 & Cascavel-PR & 2 & 933 & 24.9446 & 53.4289 & 781 \\
\hline 9 & Itaberá- São Paulo & 2 & 17 & 23.8643 & 49.1404 & 651 \\
\hline 10 & Campo Mourão-PR & 2 & 44 & 24.0437 & 52.3781 & 585 \\
\hline 11 & Castro-PR & 1 & 72 & 24.7896 & 50.0112 & 999 \\
\hline 12 & Guarapuava-PR & 1 & 218 & 25.3907 & 51.4628 & 1098 \\
\hline 13 & Campos Novos-SC & 1 & 50 & 27.4006 & 51.2281 & 934 \\
\hline 14 & Não-Me-Toque-RS & 1 & 272 & 28.4629 & 52.8172 & 514 \\
\hline
\end{tabular}

${ }^{1}$ Region of the value for cultivation and use trial (VCU).

${ }^{2}$ Geographic coordinates in decimal degrees (DD).

COODETEC: Central Agricultural Cooperative for Technology Development and Economics; n: number of observations per site. 
Figure 1. Geographical location of Cascavel and Palotina cities, Paraná, southern Brazil, corresponding to value for cultivation and use (VCU) regions II and III, respectively.

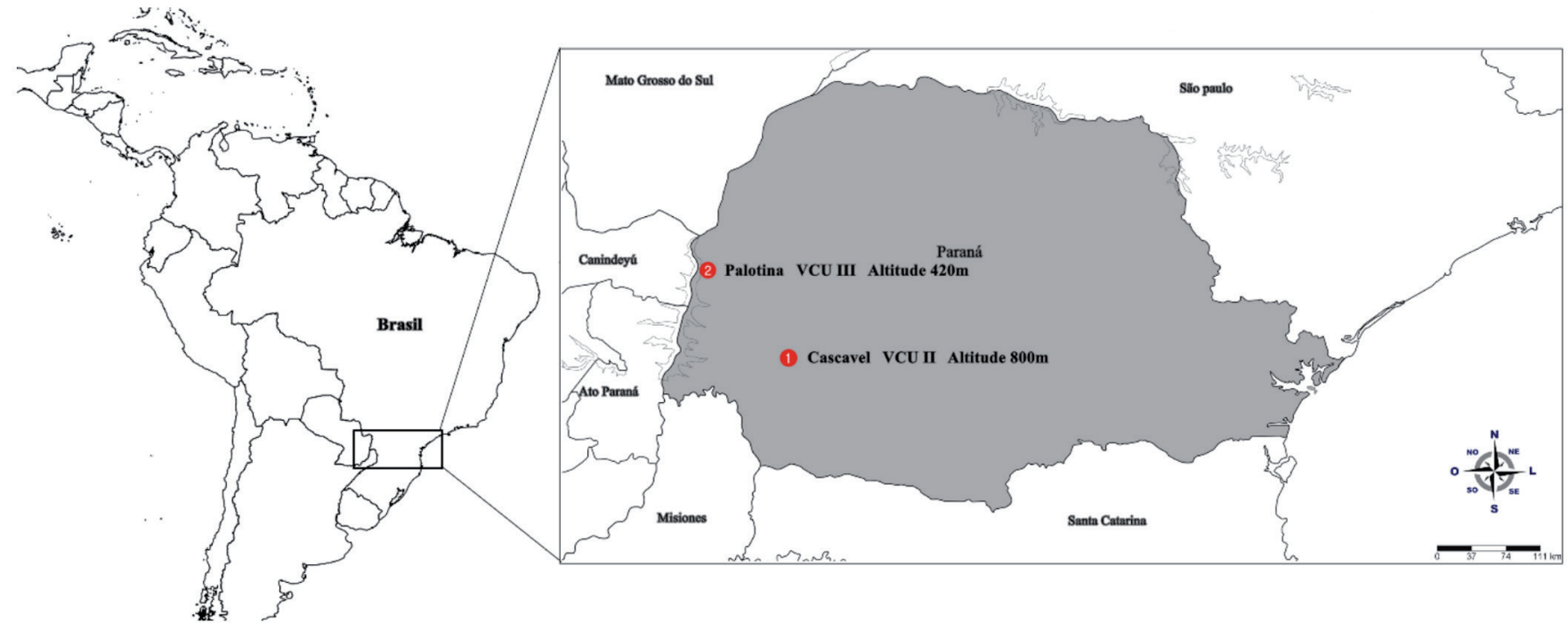

laboratory analysis. This is a common procedure in breeding programs due to the high cost of bread-making quality analysis. The samples were then sent to a partner laboratory.

\section{Grain quality analysis}

The viscoelastic properties of the dough were measured in an alveograph (Chopin Technologies, Villeneuve-la-Garenne, France), according to the method 54-30 (AACC, 2010). From this analysis, the following traits were obtained: gluten strength $\left(\mathrm{W} ; \times 10^{-4} \mathrm{~J}\right)$, tenacity $(\mathrm{P} ; \mathrm{mm})$, and extensibility $(\mathrm{L} ; \mathrm{mm})$. In addition, falling number (FN; s) was measured according to the method 56-81.03 (AACC, 2010).

\section{Statistical procedure}

Due to the dynamic annual replacement rate of lines in the breeding program, data are typically unbalanced. Every year, new lines are included for test in VCU trials, while lines already evaluated which showed unsatisfactory performance are excluded. At the end of the first year of trials, a certain number of candidate lines are eligible for the second year of evaluation. This data structure allows to access the genetic and environmental effects on the gain of important traits. We used the method proposed by Vencovsky et al. (1986), where the means of each genotype are used to calculate genetic gain. The differences observed between performances of eligible genotypes every biennium are used to estimate the environmental effect of year. Thus, for a given trait, the genetic gain is estimated by the contrast between the mean of non-eligible genotypes of a given year and the immediately previous year, excluding the environmental effect. For accurate estimates, it is necessary to adopt a base year where the environmental conditions were adequate to the crop development. We adopted the first year (2004) of the historical series as the reference year.
The genetic contrast of each biennium was measured by the follow expression: $G g_{j i}=\left(\bar{Y}_{j}-\bar{Y}_{i}\right)=\left(\bar{Y}_{C j}-\bar{Y}_{C i}\right)$, where $G g_{j i}$ represents the genetic gain of each biennium $j i$, in which $j$ is equal to $i+1$ year, $\bar{Y}_{j}$ is the overall mean of the trials in the year $j, \bar{Y}_{i}$ is the overall mean of the trials in year $i$, $\bar{Y}_{C j}-\bar{Y}_{C i}$ are the means of the eligible genotypes in the years $j$ and $i$, respectively. The 8 yr resulted in seven contrasts $\mathrm{Gg}_{\mathrm{ji}}$. The sum of these contrasts is the genetic difference throughout the evaluated period. This value, when divided by the number of bienniums, results in an annual genetic gain of the breeding program. The method is described in Cruz (2006). The annual gain in the trait unit was obtained by the following expression:

$$
G g_{a}=\left(G g_{a(\%)} \times \bar{Y}_{i}\right) / 100
$$

where $\mathrm{Gg}_{\mathrm{a}(\%)}$ is the anual genetic gain in percentage and $\bar{Y}$ is the overall mean for the trait in the first year. Analysis was performed using the Genes program (Cruz, 2013).

We used the method described by Oury et al. (2012) to correct the year effect on the dataset. Thereafter, the linear regression and descriptive analysis (box plot) were performed. The corrected data were obtained by the following expression $y c_{j}^{A i+1}=y_{j}^{A i+1}+d_{A i A i+1}$, where $y_{j}^{A i}$ is genotype mean $j$ in the $A i$ year; $y_{j}^{A i+1}$ is the genotype mean $j$ in the next year, $y c_{j}^{A i+1}$ is the corrected genotype mean $j$, and $d_{A i A i+1}$ was obtained by the following expression: $d_{A i A i+1}=\left(\sum_{j=1}^{n_{A i A i}+1}\left(y_{j}^{A i}-y_{j}^{A i+1}\right)\right) / \mathrm{n}_{A i A i+1}$, where $\mathrm{n}_{A i A i+1}$, is the number of eligible genotypes in the year $A i$ and $A i+1$. Using this procedure, we measured the effect of the year by the average difference between eligible genotypes each biennium. This estimated effect was then used to correct the mean of all genotypes, similar to the method presented by Vencovsky et al. (1986) for genetic gain estimation. For the year $A i+2$, the corrected values were obtained by the following expression:

$$
y c_{j}^{A i+2}=y_{j}^{A i+2}+d c_{A i+1 A i+2}
$$

where $d c_{A i+1 A i+2}=\left(\sum_{j=1}^{n A i+1 A i+2}\left(y_{j}^{A i+1}-y_{j}^{A i+2}\right)\right) / \mathrm{n}_{A i+1 A i+2}$. 
We proceeded in this way until the last year of the historical series. The linear regression analysis between the site latitude and baking quality traits were performed from the mean of genotypes at each site. A matrix $p * n$ (34 genotypes vs. 14 sites, Table 1) was previously analyzed in the GGE biplot program (Yan, 2001) in order to impute missing values due to the data unbalanced characteristic (42\% of the matrix). Twentysix cycles of singular value decomposition (SVD) were necessary for the missing values estimation (Yan, 2013). Next, we estimated the mean of each trait in each environment, which were used in simple linear regression analysis, taking as independent variable the latitude values of each site, in decimal. The SigmaPlot v.11 program (Systat Software, San Jose, California, USA) was used to prepare the graphics.

\section{RESULTS AND DISCUSSION}

The use of contrast between means in order to estimate the gain in key traits from multi-environment trial data is common in scientific research (Storck et al., 2005; Cargnin et al., 2009; Brisson et al., 2010; Oury et al., 2012). It is a flexible method (Soares et al., 1994) and can be used for data without replicate, which is common in the measurement of baking quality traits in wheat breeding programs.

The total estimated gain for gluten strength (W) was $0.54 \% \mathrm{yr}^{-1}$ (Table 2). In terms of trait unit, this value represents $1.82 \times 10^{-4} \mathrm{~J} \mathrm{yr}^{-1}$. It can be noted that gain due exclusively to the genetic component had higher magnitude $\left(1.30 \% \mathrm{yr}^{-1}\right.$ or $\left.4.44 \times 10^{-4} \mathrm{~J} \mathrm{yr}^{-1}\right)$. In wheat grown in Spain in the last century, Sanchez-Garcia et al. (2015) observed $1.38 \% \mathrm{yr}^{-1}$ of genetic gain in W. In Italy, Subira et al. (2014) reported $0.54 \% \mathrm{yr}^{-1}$ of genetic gain for the same trait. In general, genetic gain seen in this study is high and reflects the plant breeding efforts to achieve higher bread-making quality in modern wheat genotypes.

Estimated genetic gains in $\mathrm{W}$ and tenacity $(\mathrm{P})$ were environment dependent, that is, were partially counterbalanced

Table 2. Genotype substitution rates (\%) and gain estimations in the wheat breeding program due to genetic and environment effects for some bread-making quality traits.

\begin{tabular}{lcccc}
\hline & \multicolumn{4}{c}{ Substitution rates (\%) } \\
\cline { 2 - 5 } Bienniums & Inclusion & Exclusion & Maintenance & Replacement \\
\hline $2006-2005$ & 43.1 & 35.9 & 20.9 & 67.3 \\
$2007-2006$ & 25.2 & 26.0 & 48.9 & 34.0 \\
$2008-2007$ & 36.2 & 27.6 & 36.2 & 50.0 \\
$2009-2008$ & 14.1 & 43.0 & 43.0 & 24.7 \\
$2010-2009$ & 51.7 & 29.1 & 19.2 & 72.9 \\
$2011-2010$ & 34.8 & 41.5 & 23.8 & 59.4 \\
$2012-2011$ & 36.8 & 34.2 & 28.9 & 56.0 \\
Mean & 34.6 & 33.9 & 31.6 & 52.0 \\
Gain in the breeding program & & & \\
\multicolumn{1}{c}{ Genetic } & W\% $\left(\times 10^{-4} \mathrm{~J}\right)$ & P\% (mm) & L\% (mm) & FN\% (s) \\
Environmental & $1.30(4.44)^{\dagger}$ & $2.11(2.01)$ & $-0.93(-0.71)$ & $0.00(-0.02)$ \\
Total & $-0.78(-2.63)$ & $-6.72(-6.40)$ & $7.65(5.81)$ & $-0.05(-0.19)$ \\
& $0.54(1.82)$ & $-4.61(-4.39)$ & $6.7(5.09)$ & $-0.06(-0.21)$ \\
\hline
\end{tabular}

Value in parenthesis is the trait unit.

W: Gluten strength; P: tenacity; L: extensibility; FN: falling number. by adverse effects of agro-climatic conditions over the years $\left(-0.78\right.$ and $-6.72 \% \mathrm{yr}^{-1}$, respectively). In a short historical series, as used in this investigation, the occurrence of adverse agroclimatic conditions in a crop season is sufficient to compromise the overall environmental gain. In the 2010 season, we observe drought stress during grain filling in Cascavel and Palotina. In that year, the average rainfall in the months coinciding with the grain filling was about $50 \%$ lower than in the years with regular water regime. In addition, in 2010 there was a reduction in extensibility (L) and an increase in $\mathrm{W}, \mathrm{P}$, and falling number $(\mathrm{FN})$ in contrast to 2009 crop season (Table 2). Under drought stress, Li et al. (2013) observed an increase in $\mathrm{P}$ and decrease in $\mathrm{L}$, resulting in high $\mathrm{P} / \mathrm{L}$ ratio and, consequently, low leaf volume; an important trait for bread-making quality.

The results show $2.11 \% \mathrm{yr}^{-1}$ of genetic gain for $\mathrm{P}$ and decrease for $\mathrm{L}\left(-0.93 \% \mathrm{yr}^{-1}\right)$. This implies $3.04 \% \mathrm{yr}^{-1}$ of genetic gain to $\mathrm{P} / \mathrm{L}$ ratio. Hence, there is a genetic trend to increase $\mathrm{P} / \mathrm{L}$ ratio configuration, which may cause unbalanced dough due to the search for cultivars with high baking quality. Investigating 20 bread wheat cultivars released during the twentieth century in Spain, SanchezGarcia et al. (2015) observed $0.99 \% \mathrm{yr}^{-1}$ of genetic gain in $\mathrm{P}$ and a decrease in $\mathrm{L}\left(-0.46 \% \mathrm{yr}^{-1}\right)$, causing a disequilibrium $\mathrm{P} / \mathrm{L}$ ratio in modern cultivars. Similar result is shared by Guarda et al. (2004) in Italian wheat. The high $\mathrm{P}$ and consequent high $\mathrm{P} / \mathrm{L}$ ratio, is not interesting for baking process because dough becomes too tenacious and too porous during fermentation and the loaf volume is reduced. In a study involving Canadian wheat, Clarke et al. (2010) emphasized the existence of sufficient genetic variability to obtain genotypes with high $\mathrm{W}$ and balanced $\mathrm{P} / \mathrm{L}$.

Breeding programs need to be dynamic, constantly renovating the lines in the final test phase (advanced line tests). On average, the breeding program in the current investigation tests around 57 new elite lines every year for bread-making quality. The annual rate of lines renovation was $52 \%$ and reflect the breeding program dynamism in the search process for higher bread-making quality genotypes. For grain yield, other researchers reported lower renovation rates (Cargnin et al., 2008; 2009). The genotypes maintenance rate was $31.6 \%$, indicating that almost onethird of the genotypes was maintained under evaluation in more than $1 \mathrm{yr}$. The high maintenance rate allowed us to estimate with adequate precision, the environmental variation between years (random effect). As a consequence, it reduces the effects of experimental error and deviations due to Genotype $\times$ Environment interaction $(\mathrm{G} \times \mathrm{E})$.

The FN is an indicator of the alpha-amylase enzyme activity in the seed and is related to the remobilization of energy reserves for the germination process (Atwell, 2001). Thus, FN indicates the occurrence of pre-harvest sprouting. Brazilian wheat crop areas are often subject to rain in the pre-harvest moment, compromising the hectoliter mass as well as the bread-making quality. In this sense, breeders generally seek for genotypes with tolerance/resistance to pre-harvest sprouting. As expected, we did not observe 
genetic or environmental gain $\left(0.0 \% \mathrm{yr}^{-1}\right.$ in both) for FN (Table 2). Nevertheless, it is clear that the environmental effect is extremely important and determines the direction and magnitude of the contrasts each biennium (Figure 2d). This is because the FN variation depends mainly on the occurrence of high moisture for a relative period of time in pre-harvest. The absence of this condition will result in high FN values, even in susceptible genotypes. Laidig et al. (2017) analyzing data from VCU trials in Germany also observed that FN was highly influenced by environment.

We observed a peak in the accumulated genetic gain for W and P in 2008-2009 crop season (Figure 2a and 2b). Possibly, the dilution in the genetic gains after this period was due to the changes in the goals of the breeding program. At that time, breeders redirected efforts to develop cultivars adapted to colder regions of the country (high latitude regions), which demanded changes in the germplasm base. Thus, they resorted to national wheat germplasm, which generally exhibits lower $\mathrm{W}$ and $\mathrm{P}$ but more resistance to diseases. The similar behavior observed between $\mathrm{W}$ and $\mathrm{P}$ is explained by the correlation $0.60 * *$ (Figure $3 \mathrm{~b}$ ) and is in agreement with other authors ( $\mathrm{Li}$ et al., 2013). The gluten composes about $80 \%$ of the protein fraction of wheat grain endosperm, consisting of subunits of glutenins and gliadins (Peña et al., 2002; 2005). Glutenins give tenacity to the dough while gliadins are responsible for extensibility (Peña et al., 2005). Of these two fractions, glutenin is the main responsible for the gluten strength (Peña et al., 2002). Therefore, this explains the correlation between $\mathrm{W}$ and $\mathrm{P}$ as well as the genetic gain similar in both traits.

Notoriously, the year effect is usually higher than the site, genotype and interaction effects in the studies of qualitative aspects of the flour. The strong dependence of the evaluated traits on the year effect is easily seen in Figure 2. With the exception of the trait $\mathrm{L}$, which was positively affected, the remaining traits showed fluctuation in the accumulated gain over the years. In $\mathrm{W}$, the maximum environmental gain occurred in the 2010 crop season, but was followed by a drastic reduction by around $44.0 \times 10^{-4} \mathrm{~J}$ in the 2011 crop season, possibly caused by the occurrence of frosts during the flowering time in 2011 (CONAB, 2012). Thus, it is evident the importance of evaluation elite wheat lines for more than $1 \mathrm{yr}$ when the aim is to determine the breadmaking quality potential.

The means of $\mathrm{W}$ ranged from 235.5 to $289.5 \times 10^{-4}$ $\mathrm{J}$ in 2005 and 2009, respectively (Figure 3a). Through the years, the selection of one or a few traits implies an increase of favorable alleles. Although, breeding in the last

Figure 2. Trends in genetic and environmental accumulated gains of wheat breeding over the period of 2005 through 2012 for the following traits: gluten strength (a), tenacity (b), extensibility (c) and falling number (d).
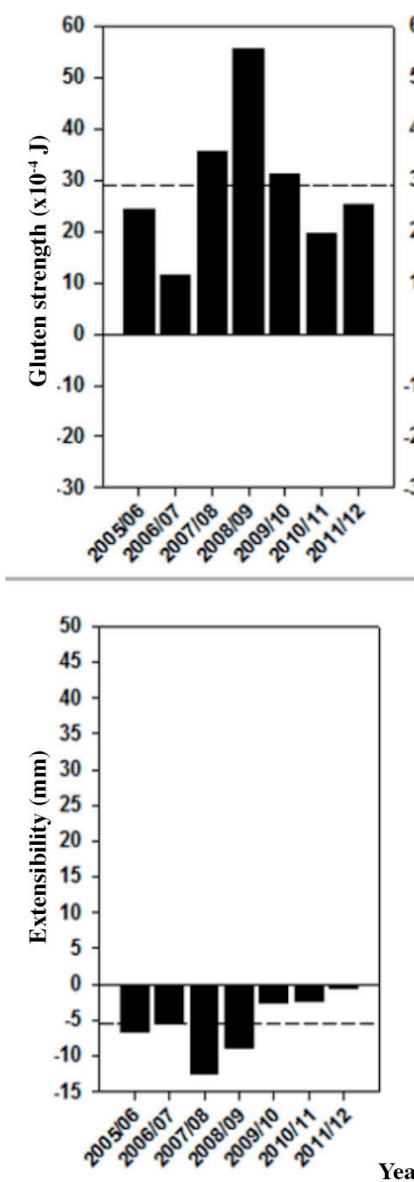

(a)

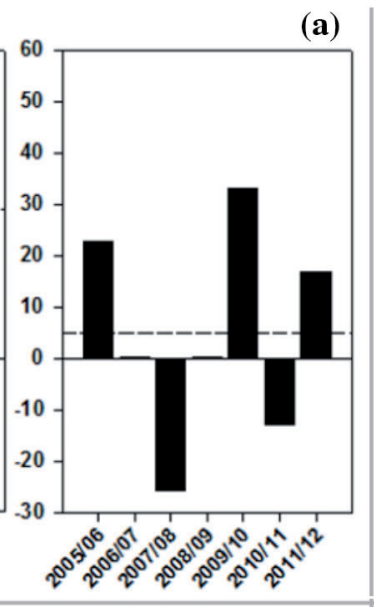

(c)

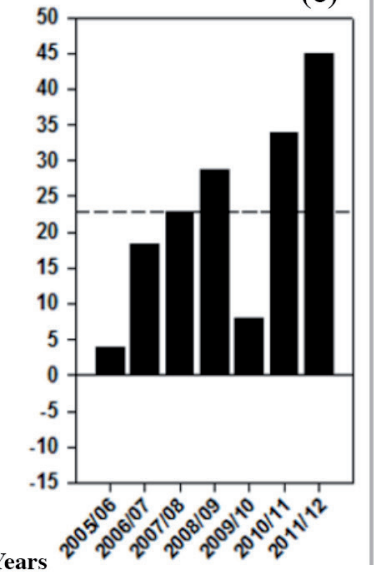

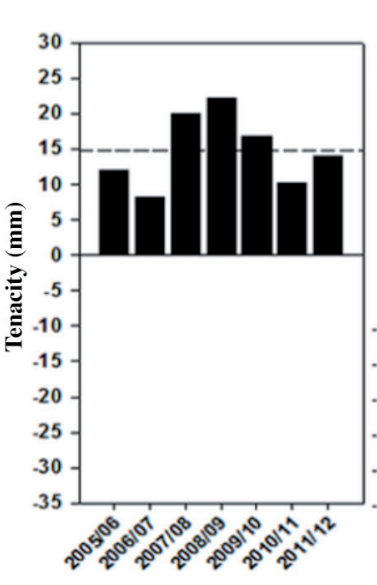
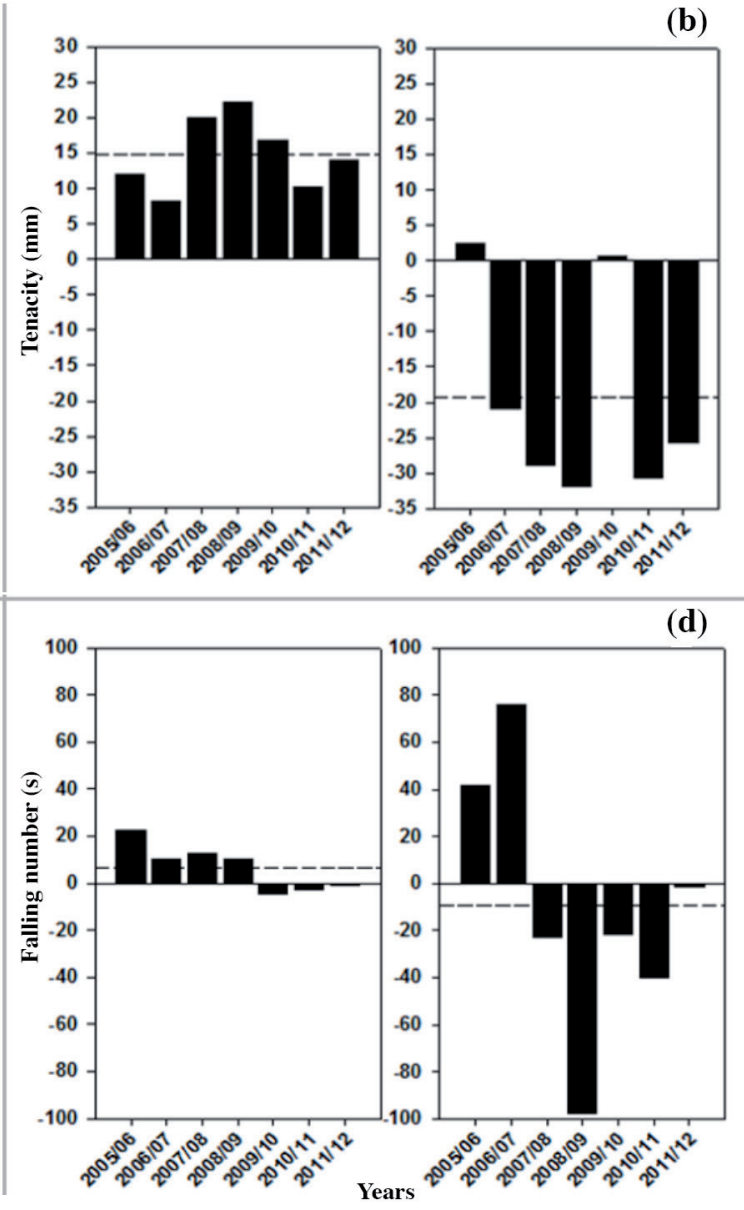

For each subfigure, left bar plot graph represents genetic gain, and right one represents environmental gain. 
Figure 3. Boxplot for gluten strength values (a), Pearson's correlation coefficient of the tenacity with gluten strength (b), and linear regressions between the independent variable latitude vs. gluten strength (c), and latitude vs. tenacity and extensibility in bread wheat (d).
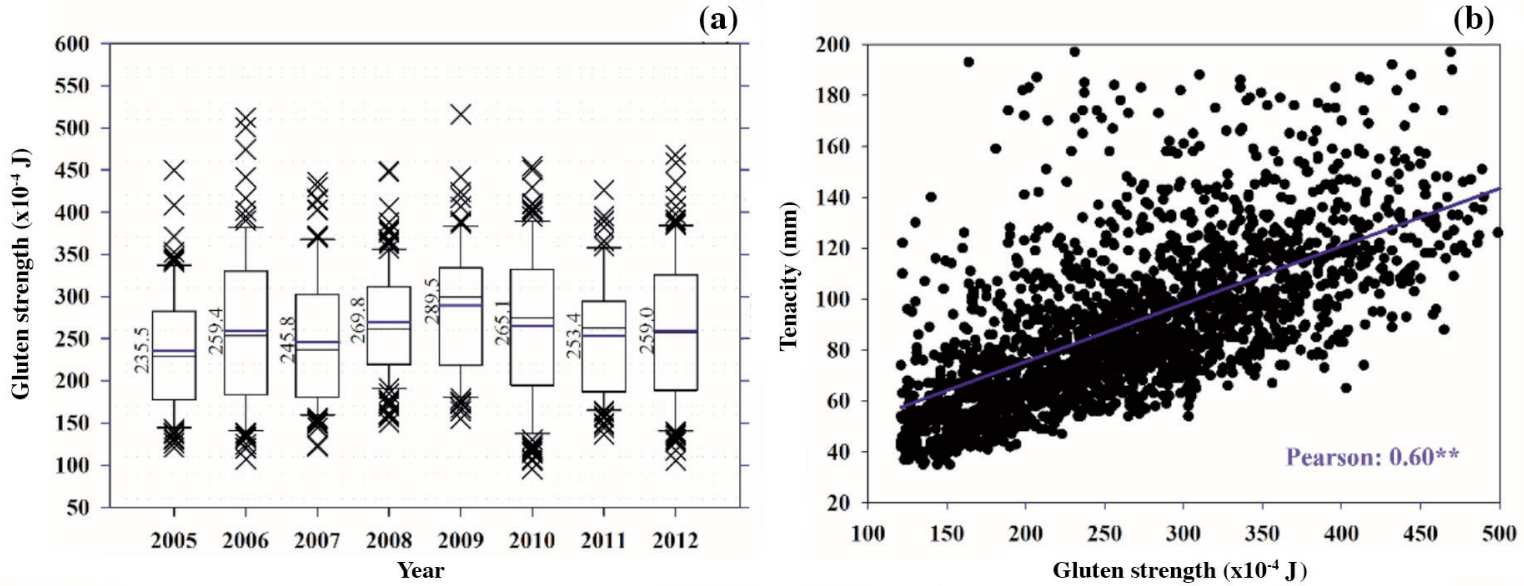

(c)
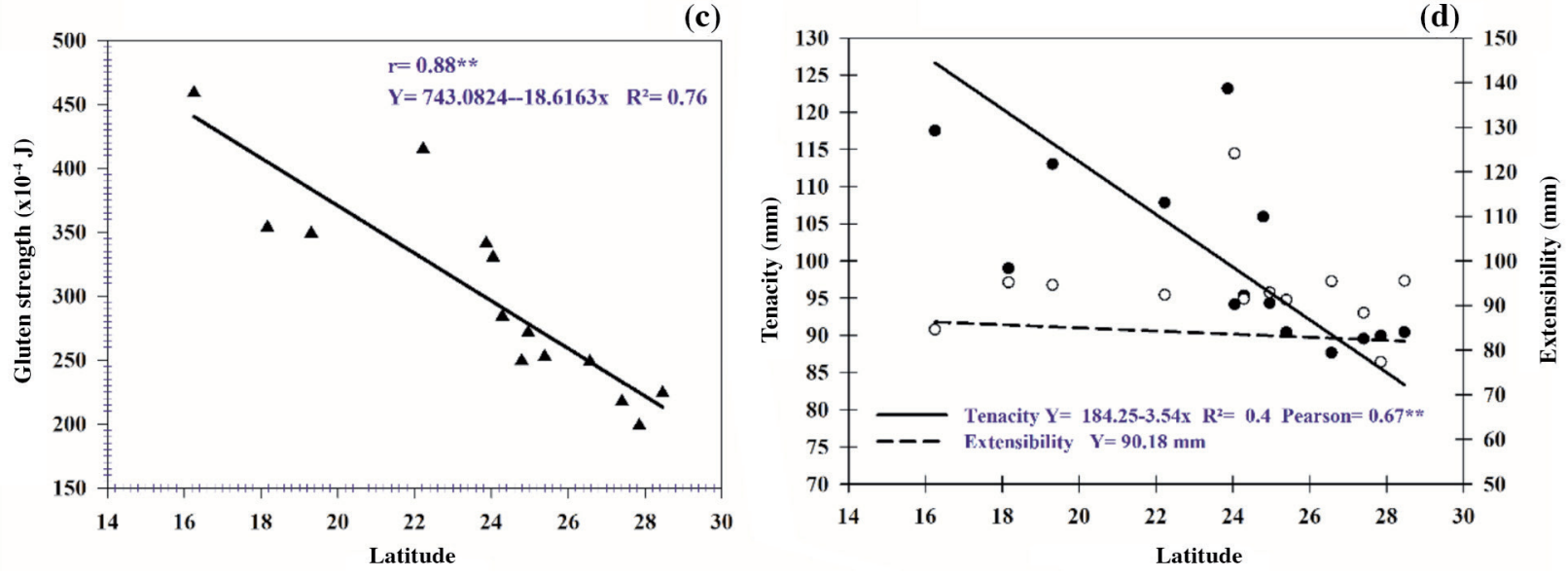

**Significant at 0.01 probability level.

century have favored the grain yield and adaptive traits, we observed a wide variability in $\mathrm{W}$ for each tested years. This genetic variability would be sufficient to enable long-term gains in wheat bread-making quality traits. Furthermore, it can be noticed that data are more scattered above the median, characterizing genetic variability for high W.

A negative and high magnitude correlation between latitude and $\mathrm{W}$ was observed $(\mathrm{r}=0.88 ; \mathrm{p}<0.01)$ (Figure $3 \mathrm{c})$. By simple linear regression, we noticed that each degree that latitude rises there is a gradual decrease of approximately $18.6 \times 10^{-4} \mathrm{~J}$ in W. Similarly, negative correlation of moderate magnitude between $\mathrm{P}$ and latitude ( $\mathrm{r}=0.67 ; \mathrm{p}<0.01)$ was observed, with a reduction of $3.54 \mathrm{~mm}$ each degree to which latitude increased (Figure $3 \mathrm{~d})$. This is due to the decrease in temperature as latitude increases. The temperature is critical in defining the wheat bread-making quality. When it is moderately high, favors the accumulation of protein in the grain, promoting better quality. On the other hand, we did not find a significant effect of the latitude on L (Figure 3d). Therefore, in Brazilian agroclimatic conditions, it is possible to reduce the $\mathrm{P} / \mathrm{L}$ ratio increasing the latitude of the crop site. This information can be useful in the recommendation of wheat cultivars in Brazil.

The genetic gain for a given crop can be estimated based on the evaluation of historical varieties in trials during different years and sites. For the 36 cultivars released between the years 1999 and 2013, used as controls in the VCU trials, we found no correlation between $\mathrm{W}$ and the year of release $(r=0.0$; Figure $4 \mathrm{a})$. The same result was found for $\mathrm{L}$ and $\mathrm{P}$ (Figures $3 \mathrm{~b}$ and $3 \mathrm{c}$ ). However, this is not an unfavorable scenario, because $83 \%$ of the cultivars showed $\mathrm{W}$ values higher than $220 \times 10^{-4} \mathrm{~J}$, which corresponds to the minimum threshold for classification as bread quality (Brazil, 2010). Although there are many cultivars available in the market, only a fraction of these occupy significant areas and in general, cultivars with lower bread-making quality tend to be less cultivated. In addition, there is demand for wheat with a low W in Brazil, especially for cookies production, which explains the presence of some low W cultivars. This market represents around $10 \%$ of the wheat consumed (ABITRIGO, 2016). Also, the main goal of wheat breeders is the increase of grain yield while maintaining bread-making quality at acceptable levels.

For future studies, it is suggested the assessment of the genetic gain in wheat for bread-making quality in the VCU1 region, characterized by environments with mild winter temperatures. Due to the environmental dependency 
Figure 4. Cultivars dispersion across the years from 1999 to 2013 for the following traits: gluten strength (a), extensibility (b), and tenacity (c).

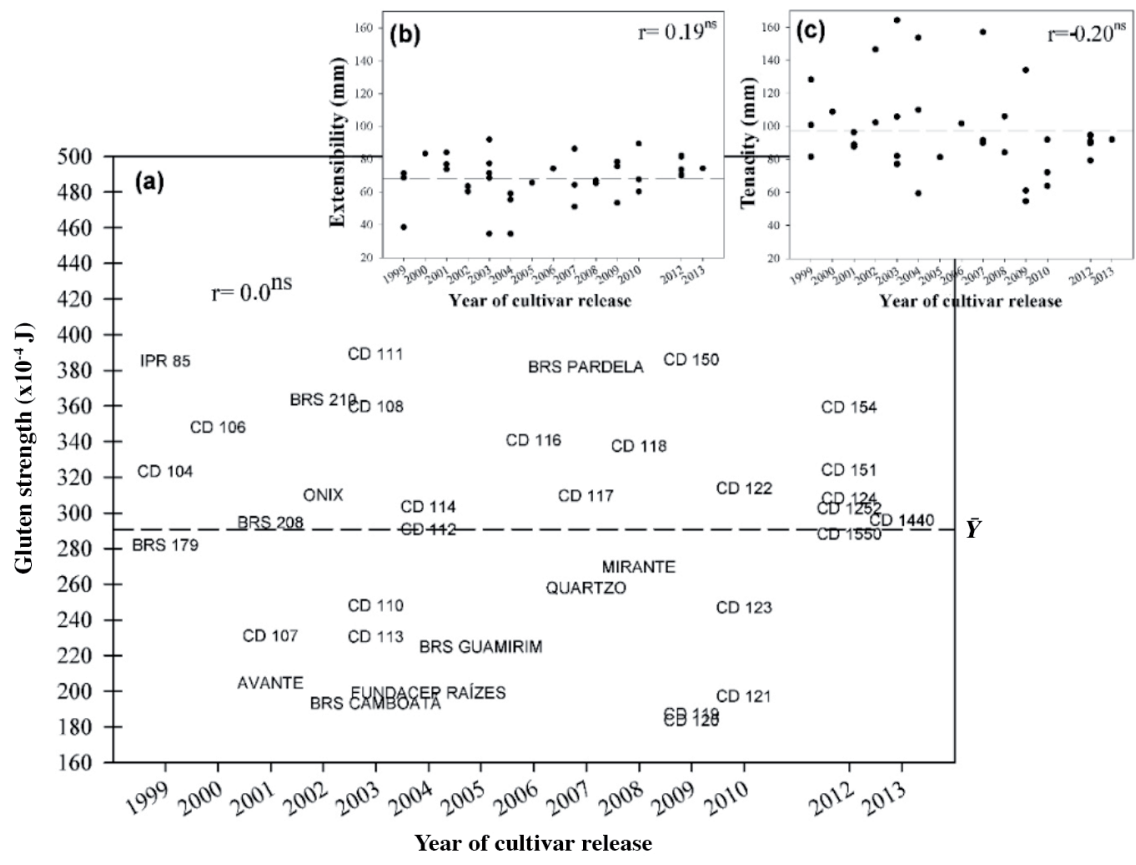

$\bar{Y}$ : Indicates the overall mean (dashed line), ${ }^{\text {ns }}$ : nonsignificant according the t-test.

in the expression of the bread-making quality traits, caution is needed in the removal of genotypes with insufficient quality evaluated in just $1 \mathrm{yr}$. Addition studies are required in order to understand the genetic basis of $\mathrm{P} / \mathrm{L}$ ratio and highthroughput techniques may facilitate the evaluation of this trait.

\section{CONCLUSIONS}

This study is one of the first to use data from bread-making quality traits evaluated in multi-environment trials to estimate genetic gains across historical data records. We estimated the genetic gain for gluten strength in around $1.30 \% \mathrm{yr}^{-1}\left(1.82 \times 10^{-4} \mathrm{~J} \mathrm{yr}^{-1}\right)$ while the environmental effect ranged through the years and partially counterbalanced genetic gains

The process of wheat breeding for high bread-making quality resulted in a tendency of disequilibrium in tenacity/ extensibility ratio with a genetic gain of $3.04 \% \mathrm{yr}^{-1}$. This ratio tends to reduce as it increases the latitude of the crop site.

The environment component changes the direction and magnitude of the total gains in investigated traits and indicates the need for evaluation of genotypes in more than $1 \mathrm{yr}$ in multi-environment trials.

\section{ACKNOWLEDGEMENTS}

The authors are grateful to Coordination for the Improvement of Higher Education Personnel (CAPES) for the scholarship granted and Central Agricultural
Cooperative for Technology Development and Economics (COODETEC) for providing the dataset used for this study.

\section{REFERENCES}

AACC. 2010. Approved methods of analysis. 11 ${ }^{\text {th }}$ ed. American Association of Cereal Chemists (AACC) International, Saint Paul, Minnesota, USA.

ABITRIGO. 2016. Associação Brasileira da Industria do Trigo. Farinha de trigo. São Paulo, Brasil. Avaliable at http://www. abitrigo.com.br/farinha-de-trigo.php (accessed May 2016).

Atroch, A.L., e Nunes, G.H.S. 2000. Progresso genético em arroz de várzea úmida no estado do Amapá. Pesquisa Agropecuária Brasileira 35:767-771. doi:10.1590/S0100204X2000000400013.

Atwell, W.A. 2001. Wheat flour. American Association of Cereal Chemists, Saint Paul, Minnesota, USA.

Bilgin, O., Guzmán, C., Başer, I., Crossa, J., and Korkut, K.Z. 2015. Evaluation of grain yield and quality traits of bread wheat genotypes cultivated in northwest Turkey. Crop Science 56:7384. doi:10.2135/cropsci2015.03.0148.

Brazil. 1994. Ministério da Agricultura, do Abastecimento e da Reforma Agrária. Portaria n ${ }^{\circ} 167$ de 29 de julho de 1994. Diário Oficial 147:11.640-11.642.

Brazil. 2010. Ministério da Agricultura Pecuária e Abastecimento. Instrução Normativa $n^{\circ}$ 38, of 30 of November, 2010. Regulamento técnico do trigo. Brasília, Brazil. Available at http://www.codapar.pr.gov.br/arquivos/File/pdf/ TrigoInstrucaoNormativa3810.pdf (accessed December 2013).

Brisson, N., Gate, P., Gouache, D., Charmet, G., Oury, F.X., and Huard, F. 2010. Why are wheat yields stagnating in Europe? A comprehensive data analysis for France. Field Crops Research 119:201-212. doi:10.1016/j.fcr.2010.07.012. 
Cargnin, A., Souza, M.A., and Fronza, V. 2008. Progress in breeding of irrigated wheat for the Cerrado region of Brazil. Crop Breeding and Applied Biotechnology 8:39-46.

Cargnin, A., Souza, M.A., Fronza, V., and Fogaça, C.M. 2009. Genetic and environmental contributions to increased wheat yield in Minas Gerais, Brazil. Scientia Agricola 66:317-322. doi:10.1590/S0103-90162009000300006.

Clarke, J.M., Clarke, F.R., and Pozniak, C.J. 2010. Forty-six years of genetic improvement in Canadian durum wheat cultivars. Canadian Journal of Plant Science 90:791-801. doi:10.4141/cjps 10091 .

CONAB. 2012. Acompanhamento da safra brasileira, safra 2011/2012 (quarto levantamento). Companhia Nacional de Abastecimento (CONAB), Brasília-DF, Brasil. Available at http://www.conab.gov.br/conteudos.php? $\mathrm{a}=1253 \& \mathrm{t}=2$ (accessed 2 March 2016).

Cormier, F., Faure, S., Dubreuil, P., Heumez, E., Beauchêne, K., Lafarge, S., et al. 2013. A multi-environmental study of recent breeding progress on nitrogen use efficiency in wheat (Triticum aestivum L.) Theoretical Applied Genetics 126:3035-3048. doi:10.1007/s00122-013-2191-9.

Crespo-Herrera, L.A., Crossa, J., Huerta-Espino, J., Autrique, E., Mondal, S., Velu, G., et al. 2017. Genetic yield gains in CIMMYT's international elite spring wheat yield trials by modeling the genotype $\times$ environment interaction. Crop Science 57:1-13. doi:10.2135/cropsci2016.06.0553.

Cruz, C.D. 2006. Programa Genes: Biometria. Universidade Federal de Viçosa, Viçosa, Brasil

Cruz, C.D. 2013. GENES - a software package for analysis in experimental statistics and quantitative genetics. Acta Scientiarum Agronomy 35:271-276. doi:10.4025/actasciagron. v35i3.21251.

De Vita, P., Nicosia, O.L.D., Nigro, F., Platani, C., Riefolo, C., Di, F.N., et al. 2007. Breeding progress in morpho-physiological, agronomical and qualitative traits of durum wheat cultivars released in Italy during the $20^{\text {th }}$ century. European Journal of Agronomy 26:39-53. doi:10.1016/j.eja.2006.08.009.

Guarda, G., Padovan, S., and Delogu, G. 2004. Grain yield, nitrogen-use efficiency and baking quality of old and modern Italian bread-wheat cultivars grown at different nitrogen levels. European Journal of Agronomy 21:181-192. doi:10.1016/ j.eja.2003.08.001.

Hucl, P., Briggs, C., Graf, R.J., and Chibbar, R.N. 2015. Genetic gains in agronomic and selected end-use quality traits over a century of plant breeding of Canada western red spring wheat. Cereal Chemistry Journal 92:537-543. doi:10.1094/cchem-0215-0029-r.

Laidig, F., Piepho, H.-P., Rentel, D., Drobek, T., Meyer, U., and Huesken, A. 2017. Breeding progress, environmental variation and correlation of winter wheat yield and quality traits in German official variety trials and on-farm during 1983-2014. Theoretical Applied Genetics 130:223-245. doi:10.1007/s00122016-2810-3.

Li, Y., Wu, Y., Hernandez-Espinosa, N., and Peña, R.J. 2013. The influence of drought and heat stress on the expression of end-use quality parameters of common wheat. Journal of Cereal Science 57:73-78. doi:10.1016/j.jcs.2012.09.014.

MacRitchie, F. 2016. Seventy years of research into breadmaking quality. Journal of Cereal Science 70:123-131. doi:10.1016/ j.jcs.2016.05.020.
Matus, I., Mellado, M., Pinares, M., Madariaga, R., and del Pozo, A. 2012. Genetic progress in winter wheat cultivars released in Chile from 1920 to 2000. Chilean Journal of Agricultural Research 72:303-308. doi:10.4067/S0718-58392012000300001.

Ormoli, L., Costa, C., Negri, S., Perenzin, M., and Vaccino, P. 2015. Diversity trends in bread wheat in Italy during the 20th century assessed by traditional and multivariate approaches. Scientific Reports 5:1-7. doi:10.1038/srep08574.

Oury, F.X., Godin, C., Mailliard, A., Chassin, A., Gardet, O., Giraud, A., et al. 2012. A study of genetic progress due to selection reveals a negative effect of climate change on bread wheat yield in France. European Journal of Agronomy 40:28-38. doi:10.1016/j.eja.2012.02.007.

Peña, E., Bernardo, A., Soler, C., and Jouve, N. 2005. Relationship between common wheat (Triticum aestivum L.) gluten proteins and dough rheological properties. Euphytica 143:169-177. doi:10.1007/s10681-005-3157-z.

Peña, R.J., Trethowan, R., Pfeiffer, W.H., and Ginkel, M.V. 2002. Quality (end-use) improvement in wheat: Compositional, genetic, and environmental factors. Journal of Crop Production 5(1-2):1-38. doi:10.1300/J144v05n01_02.

Ribeiro, N.D., Possebon, S.B., e Storck, L. 2003. Progresso genético em caracteres agronômicos no melhoramento do feijoeiro. Ciência Rural 33:629-633. doi:10.1590/S010384782003000400006.

Sanchez-Garcia, M., Álvaro, F., Peremarti, A., Martín-Sánchez, J.A., and Royo, C. 2015. Changes in bread-making quality attributes of bread wheat varieties cultivated in Spain during the 20th century. European Journal of Agronomy 63:79-88 doi:10.1016/j.eja.2014.11.006.

Soares, A.A., Ramalho, M.A.P., e de Sousa, A.F. 1994. Estimativa do progresso genético obtido pelo programa de melhoramento de arroz irrigado da década de oitenta. Pesquisa Agropecuária Brasileira 29:97-104

Storck, L., Bisognin, D.A., e Cargnelutti Filho, A. 2005. Ganho genético decorrente da substituição anual de cultivares de milho. Pesquisa Agropecuária Brasileira 40:881-886. doi:10.1590/ S0100-204X2005000900007.

Subira, J., Peña, R.J., Álvaro, F., Ammar, K., Ramdani, A., and Royo, C. 2014. Breeding progress in the pasta-making quality of durum wheat cultivars released in Italy and Spain during the $20^{\text {th }}$ Century. Crop and Pasture Science 65:16-26. doi: $10.1071 / \mathrm{CP} 13238$.

Vázquez, D., Berger, A.G., Cuniberti, M., Bainotti, C., Miranda, M.Z., Scheeren, P.L., et al. 2012. Influence of cultivar and environment on quality of Latin American wheats. Journal of Cereal Science 56:196-203. doi:10.1016/j.jcs.2012.03.004.

Vencovsky, R., Morais, A.R., Garcia, J.C., e Teixeira, N.M. 1986. Progresso genético em vinte anos de melhoramento do milho no Brasil. p. 300-307. In XVI Congresso Nacional de Milho e Sorgo, Belo Horizonte. Embrapa-CNPMS, Sete Lagoas, Minas Gerais, Brasil.

Yan, W. 2001. GGE Biplot - a Windows application for graphical analysis of multienvironment trial data and other types of two-way data. Agronomy Journal 93:1111-1118. doi:10.2134/agronj2001.9351111x.

Yan, W. 2013. Biplot analysis of incomplete two-way data. Crop Science 53:48-57. doi:10.2135/cropsci2012.05.0301. 